\title{
Powder Aerosol Dosage Form
}

National Cancer Institute

\section{Source}

National Cancer Institute. Powder Aerosol Dosage Form. NCI Thesaurus. Code C42971.

A powder composed of active and/or inert ing redient(s) and packaged under pressure.

Ingredients are released upon activation of an appropriate valve system. 